\title{
THE EFFECT OF PRICE INCREASES ON FRESH MEAT CONSUMPTION IN TURKEY
}

\author{
Bekir Demirtas $^{1}$ \\ ${ }^{1}$ Department of Agricultural Economics, Faculty of Agriculture, Mustafa Kemal University, Hatay, Turkey \\ To cite this article:DEMIRTAS BEKIR.2018.The Effect of PriceIncreases on Fresh Meat Consumption \\ in Turkey. Acta Universitatis Agriculturae et Silviculturae Mendelianae Brunensis, 66(5): 1249-1259.
}

To link to this article: https://doi.org/10.11118/actaun201866051249

\begin{abstract}
The rapid increase of the red meat price in Turkey in the recent years negatively affects its consumption. Consumers are seeking to compensate for the need for animal protein with cheaper substitution products. In this study, the effects of consumer attitudes, product prices and some other variables on the factors affecting consumption of fresh red meat are examined. A 58-item questionnaire measuring Behavior and Behavioral Intention was applied to 455 consumers in the Eastern Mediterranean Region of Turkey based on the Theory of Planned Behavior. In the study, participants' consumption of fresh red meat and white meat was examined together. In the analysis of the data, correlation, independent samples' t-test and One Way Anova was used together with Path Analysis which is a Structural Equation Model technique. Price increases have a negative impact on fresh meat consumption and the effect on consumption of red meat is much higher. The Structural Model explains $80 \%$ of the Behavioral Intention variance and $87 \%$ of the Behavioral variance. In consumers' Behavior and Behavioral Intention in meat consumption Attitude, Perceived Behavioral Control and Price variable have a significant influence, while the effect of Subjective Norms on a lower level. Socioeconomic and demographic variables cause significant differences in fresh meat consumption. Reducing the increases in input prices, which is the most important source of the increase in red meat prices in Turkey, in the short and medium terms, and supporting the supply increases by sustaining its implementation in the medium and long terms should be adopted as basic policies.
\end{abstract}

Keywords: consumer price, red and white meat, demographic variables, the theory of planned behavior

\section{INTRODUCTION}

Today, many countries around the world have inadequate and unbalanced nutrition problems. People in the undeveloped countries are experiencing problems in reaching food for various reasons, even in the basics that they need, and in high-income countries, health problems arise due to overfeeding. Nevertheless, food safety and security should be regarded as one of the most fundamental rights for all people. Politicians need to reassess their food supply policies and prioritize people to maintain their nutritional needs at an adequate level.
Meat and meat products are highly nutritious foods and people need meat to be able to get a wide range of nutrients. In addition to this, meat and meat products, which is the main source of animal food, are highly nutritious in terms of proteins. Yet, meat is not in the group of homogeneous foods and meat category highly affects the composition of meat (Lorcu and Bolat, 2012; Cosgrove et al., 2005). Generally, a country's economic and social structure, climate, resources, trade policies, population, culture and lifestyle affect its food consumption. In the world, the consumption of animal-derived protein per capita along with economic development 
and urbanization has risen to around $25 \%$ in the last fifty years. However, the composition and amount of this protein source show significant differences between countries due to historical, geographical, cultural and religious factors (Sans and Combris, 2015; Akbay et al., 2007). The most important protein source in human nutrition can be obtained by consumption of animal products. Prices of animal products are generally more expensive than herbal products, especially low-income people cannot get enough of these nutrients.

Food choice of the people is an issue for not only the food producers and distributors but also for nutritionists and health care workers. However, when it comes to food choice behavior, it is a rather complex phenomenon affected by a large number of variables. Food choice decisions are affected by transdisciplinary issues and thus it does need new perspectives to be implemented into practice and developed further. Understanding the role of the variables can help the behavior change strategies (Sobal and Bisogni, 2009; Saba and Di Natale, 1999). Media organs giving information about health issues, for example, those imparting by means of the broad communications, highly affects behaviours and attitudes of the consumers related to health (Goldberg and Hellwig, 1997). Diverse reasons other than sensorial qualities impact consumer food choices and explanation of these reasons would help to establish a superior comprehension of food consumption behavior (Higuchi, et al., 2017; Carrillo et al., 2011). Another aspect among different reasons that should be mentioned is the work by Lennernäs et al. (1997) which features the parts of quality/freshness, price, taste, healthy decisions and family inclinations, whereas Drewnowski and Darmon (2005) speculate on the impacts of taste, comfort and financial requirements on food decisions (O'Neill et al., 2014).

In the researches on demand systems in recent years, it is seen that some of these factors are started to be used together with demographic variables (Barreira and Duarte, 1997). According to the income groups of the consumers and the settlements they live in, the factors that affect the choice of meat and meat products differ. For example, reasonable price is at the forefront of low-income groups and consumers in rural areas, while in high income groups, it is health and habits, and in urban areas trust in products is placed in the first place (Sacli and Ozer, 2017; Karli, et al., 2017; Yildirim and Ceylan, 2007). In countries with low income level, such as Turkey, the price and income elasticities of the demand for animal foods is generally high. That is, consumers' incomes or changes in animal food prices are affecting the demand for these products too much. In the last 15 years in Turkey, especially red meat prices have increased much more than their alternatives (Tuik, 2017a). Because of that reason, the Turkish government has begun importing live or carcass red meat from EU countries in some periods. In addition, subsidies are applied to encourage production in the domestic market to compensate for the supply of red meat. Meat producers, meanwhile, indicate that relatively high price increases in red fresh meat and meat products are due to increases in input costs (Gul and Uzun, 2015).

The Theory of Planned Behavior (TPB) puts forward that these behavioral intentions are in control of the motivational influences on behavior. Thus, the intention is seen as behavior's closest predictor. In that case, behavioral intention is viewed as a component of mentalities, subjective standards and perceived behavioral control identified with that particular conduct. Ajzen (2011) mentioned that not just thanks to attitudes, norms and perceived control, inclinations can be understood through one or more additional factors, and these factors can be, to a limited extent, used as examples of past behaviour and wellbeing (Mitterer-Daltoé et al., 2013; Tudoran et al., 2009). In our study, it is aimed to determine how the price increases in the meat industry and which of the other important variables comes prominent, and to determine how these effects differ for red and white meat. In addition to this, determining the effects of consumer's socioeconomic and demographic features on meat consumption can be seen as another aim of the study in order to guide marketing studies to be done in the sector. Administrators who need to ensure the healthy nutrition of the community can also get some policy recommendations from these results.

\section{MATERIALS AND METHODS}

As a research area, Eastern Mediterranean Sub-region (TR63), which is located at Level-2 of the Turkish Statistical Region Classification, was selected because a similar study was not performed in this region. Three major provincial centers (Hatay, Osmaniye, and Kahramanmaraş) and districts and villages located in the administrative area of these provinces are located in this region. According to the data obtained by the end of 2017, the total population in the region is $3,190,000$. Approximately $58.6 \%$ of this population lives in the cities and $41.4 \%$ lives in the rural area. The number of consumers participating in the research was determined to be 465 for an average of $5 \%$ error margin and 95\% confidence interval for households that consumed fresh meat, and 455 of them were evaluated. The primary data were gathered between October and December 2017 from the study site. The research questionnaire was applied randomly around the markets and the butchers where the fresh meat was sold.

\section{Conceptual framework}

Although there are various models to understand consumers' food consumption behaviors, there is only one model that is used systematically for meat consumption only, which is Planned Behavior Theory (Verstuyf et al., 2012; Sobal and Bisogni, 2009). Therefore, in order to examine the consumer 
behaviors, a structural model has been introduced in accordance with the TPB theoretical model and taking into consideration, the other studies made on this subject. Responses to the question "Meat is expensive", which is included in behavioral beliefs that determine the attitude towards meat eating and is directed to consumers as an evaluative judgment and the level of importance of the "price" variable, which evaluates the quality of beliefs, in selecting or purchasing meat is considered as a separate variable in our model. The effect of the price variance on red meat and white meat that is considered to be red meat's substitute has been examined within the context of the TPB model. Three of the model's theories are preserved (Attitude, Subjective norms, and Perceived behavioral control). Attitude towards the behavior involves a thought of the consequences of the behavior (Ajzen and Fishbein, 2005). However, subjective or social norms allude to the perceived social pressure, whether to conduct a certain behavior or not. It is argued that the different components that affect food choices at a more remote level may move with the attitudes, beliefs, and perceptions of the individual (Vermeir and Verbeke, 2008; Shepherd, 1999).

In the model; attitudes, subjective norms, and perceived behavioral control elements are considered as independent variables from TPB elements. It is accepted that these variables will be sufficient to predict the meat consumption behavior and intention. According to the theory, in order for a behavior to take place, it is first necessary to form an intention for that behavior. The stronger the intent toward behavior, the greater the likelihood of a behavior. The second part of the theory consists of belief dimensions (behavior beliefs, normative beliefs, control beliefs). Attitudes, subjective norms, and beliefs that are cognitive and affective bases of perceived behavior control play a central role in TPB. Variables such as emotion, personality traits, intelligence, value, age, gender, education, knowledge, experience, race, income level are determinant in the formation of beliefs (Ajzen, 2005). TPB sees behavioral intention as a consequence of behavioral attitude, subjective norms, and perceived behavioral control. Therefore, the intention is the greatest determinant of behavior. The intention to achieve an attitude manifests a large part of the variance in behavior change (Azjen, 1991). For this reason, it can be said that Behavioral Intention $(\mathrm{BI}) \cong$ Behavior (B).

As stated in the TPB model, "Attitudes (A)" are calculated by multiplying the belief strength of each behavior. Behavioral beliefs $\left(b_{i}\right)$ are multiplied by evaluation of the quality of belief $\left(e_{i}\right)$ (Eq. 1);

$$
A=\sum_{i=1}^{I} b_{i} e_{i}
$$

When the Subjective Norms (SN) are being calculated, each normative belief $\left(n_{j}\right)$ is obtained by multiplying it by the motivation source $\left(m_{j}\right)$ (Eq. 2);

$$
S N=\sum_{j=1}^{J} n_{j} m_{j}
$$

Perceived Behavioral Control (PCB) is obtained by multiplying the control beliefs $\left(c_{k}\right)$ and the perceived power of these control factors $\left(p_{k}\right)$ (Eq. 3);

$$
\mathrm{PBC}=\sum_{k=1}^{K} c_{k} p_{k}
$$

\section{Survey and data analysis}

In the first part of the questionnaire prepared to determine consumers' meat consumption behaviors, socioeconomic and demographic characteristics of consumers and their families were determined. In the second part, 58 questions were directed to determine behavior, behavioral intention, attitude, subjective norm and perceived behavioral control within the context of TPB in order to measure meat consumption behavior and intention (for red and white meat). It has been noted that the scale and the proposals used in the questionnaire are in harmony. At the same time, various factors such as district, family structure, income and education level were taken into consideration. In addition, studies on questionnaire design for TPB were also used in the preparation

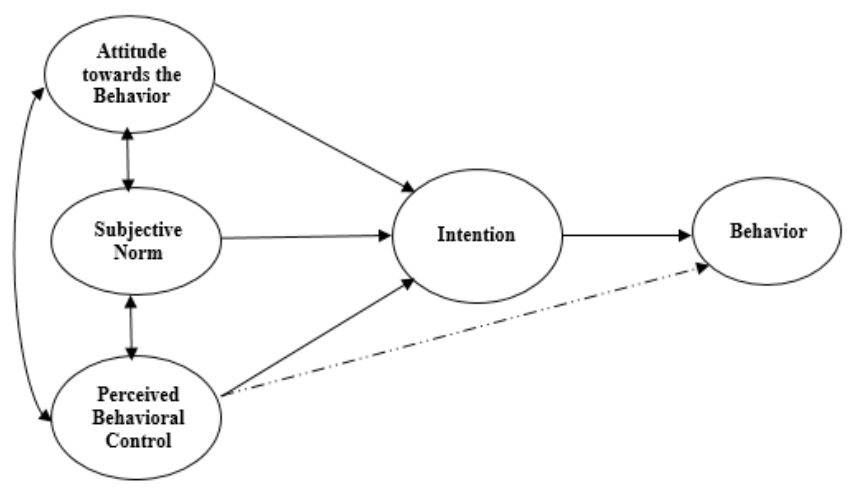

1: The Theory of Planned Behavior Original Model (Ajzen, 1991) 
of questionnaires (Ajzen, 2006). All variables were measured on a five-point scale ranging from "totally disagree" to "totally agree". The questionnaires were tested before the field study and after that their final forms are shaped. The questionnaire contains the items that measure the TPB's proposed model components and the price variance. All the questions were applied in the same way and high scores show favorable opinions. Consumption frequency and monthly meat consumption were used to determine the behavior. In determining Behavioral Intention three questions were used to measure the intention to consume meat within the next week. When measuring attitude's role toward meat consumption, Behavioral beliefs (assessment judgments and affective judgments) were determined by the 8-item questions related to "Assessing the quality of belief." The subjective norm is measured by the 9-item motivational question 6 of which corresponds social norm (social repression) and the 3 corresponds personal norm (personal responsibility, moral obligation). The perceived Behavioral Control variable was measured by 7-item questions measuring past experiences and 6-item questions measuring Control Beliefs and perceived power. In order to determine meat consumption behaviors, the data of the created model was analyzed by Path Analysis and coefficient estimations were made. To compare the differences between participants' socioeconomic and demographic characteristics and meat consumption, an Independent Sample t-test was conducted in which the sex of the household and whether they have any children (0-14 years of age) were analyzed, and other variables were analyzed by One Way ANOVA F tests with Tukey post hoc multiple comparison tests of mean scores. The Structural Model was also verified with multiple regression analysis, coefficient estimates and significance level. The data were evaluated for normality and reliability before statistical analysis and it was determined that there was no problem. IBM SPSS and Amos Release 22 software were used in the analyzes (Bryne, 2010).

\section{RESULTS AND DISCUSSION}

Meat price-consumption relation

A demand for meat is related with higher earnings and a change in food consumption preferences due to increasing demand for animal proteins (caused by urbanisation) (OECD/FAO, 2016). In 2013, the average meat consumption per capita was $33,7 \mathrm{~kg}$, and in developed countries, this number was $65 \mathrm{~kg}$ and in developing countries 25,9 (OECD/FAO, 2014). At the beginning of the period examined (2003), the difference between red meat and white meat consumer prices was approximate $\$ 4 / \mathrm{Kg}$, while at the end of the period (2017) this difference increased by more than four quarters and approached \$18/Kg (Fig. 2). For consumers' consumption of meat, especially for the low income group, price increases directly affect the amount of consumption and the type of meat consumed. Higher price increases have made chicken or fish meat, which can be an alternative to red meat, attractive to consumers. Increases in input prices (mainly feed, veterinary drug and service prices) as a basis for price increases among producers are shown. At this point, it should be taken into consideration that both carcass weight and meat yield are low in cattle and sheep in Turkey. Further work is needed in animal breeding's to increase carcass yield. According to a scenario, Turkey's annual red meat deficit will reach 250 thousand tons in 2018 (MOD, 2014). It is predicted that increases in red meat prices will reach higher levels if this scenario comes true.

Turkey's annual red meat production is approaching 1,200 thousand tons with an increase of approximately $50 \%$ in $2010-2016$ period. In this period, the average annual amount of fresh red meat per capita increased from $10.6 \mathrm{~kg}$ to $14.7 \mathrm{~kg}$. $89 \%$ of the red meat produced in Turkey is cattle and buffalo meat while the rest is sheep and goat meat (TUIK, 2017b). In 2015, fresh meat consumption per capita in Turkey was $12.4 \mathrm{~kg}$ for red meat (8.3 kg beef and veal, $4.1 \mathrm{~kg}$ sheep and goat meat) and white meat consumption was $16.5 \mathrm{~kg} /$ capita (poultry meat) (OECD/FAO, 2016). In this period,

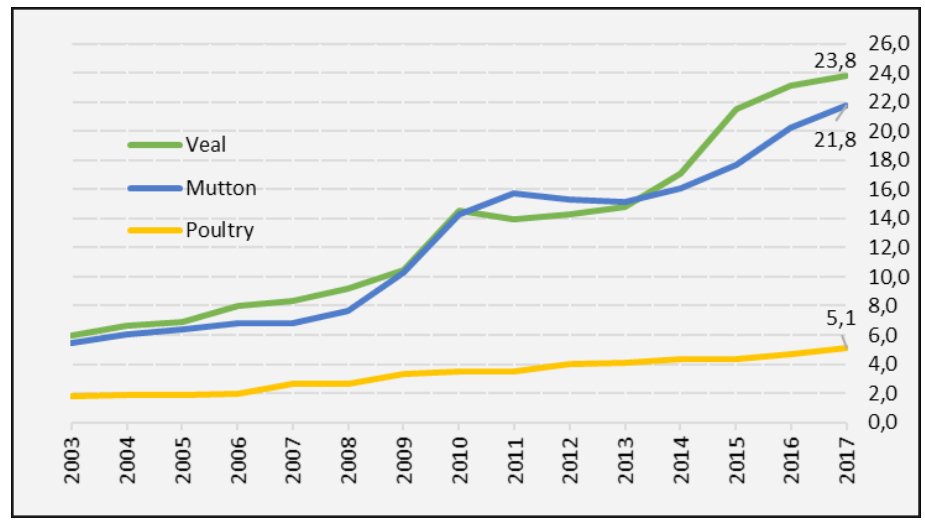

2: Annual average red and white meat consumer prices in Turkey (2003-17- \$/kg) 
the average annual consumption of red meat in the world was $20.6 \mathrm{~kg}$, the OECD countries average was $38.5 \mathrm{~kg}$, the EU-28 average was $45.6 \mathrm{~kg}$ and the US average was $47.8 \mathrm{~kg}$. These statistics show that consumers living in Turkey are consuming red meat even below the world average. The annual fresh meat consumption of participants in our study was calculated as $16.9 \mathrm{~kg} / \mathrm{per}$ capita/year for red meat and $35.2 \mathrm{~kg} /$ per capita/year for white meat. The consumption of fresh meat in the study area is higher than the average of Turkey in both kinds of meat. Consumers living in the region also consume more than twice as much white meat as their red meat consumption.

In general, women have a higher level of health consciousness and are therefore exposed in a variety of studies in which they are proved more conscious of nutrition and food consumption (Verbeke and Vackier, 2005; Kubberød, et al., 2002a; Fagerli and Wandel, 1999). In our study, $46 \%$ of the participants were women. The existence of meaningful relationships between age and people's eating habits is known. Higher wellbeing choices were seen with elderly people, which can imply that the wellbeing viewpoint in attitude was especially predominant for old people (Verbeke and Vackier, 2005). In our study participants' ages range from 19 to 70, with an average age of 35.5 years old and an elderly participant rate ( 51 years and over) of $10 \%$. Having a child at home (between 0 and 14 years) and family size affects the amount and variety of food consumed by family members. The average size of the participating families is 4.2 and the proportion of the families with children is $69 \%$. In previous studies, there was no consistent relationship between the numbers of children versus increased meat consumption with family size (Gossard and York, 2003; Worsley and Skrzypiec, 1998). Meat consumption also increases positively with education and income levels (Uzmay and Cinar, 2017; Yildirim and Ceylan, 2007; Jimin et al., 2005 ; Lea and Worsley, 2001; Blaylock et al., 1999). The monthly income of more than half of the participants in this study is between 1500-2500 TL (411-685 \$/month) and the share of consumers in the lower income group is only $17 \%$. The educational level of $76 \%$ of the participants is at primary, secondary and high school level. The percentage of university graduates (undergraduate and graduate) is only $23 \%$ and the postgraduate degree (masters and doctorate) is only $1 \%$. The distribution of participants in terms of education level and income is consistent with the characteristics of the population in the region. Finally, it has been reported in various studies that the place of residence affects the quantity and variety of food consumption due to various reasons (Yildirim and Ceylan, 2007; Gossard and York, 2003; Lea and Worsley, 2001). In our study, $16 \%$ of the participants live in rural areas while the remaining consumers live in urban areas (Tab. I).

The included price variant in the model produced negative correlations in both meat types, but correlations for red meat have higher values. The highest correlation value for both meat types is between behavior (B) and behavioral intent (BI). This study confirms that behavioral intention is the most important determinant of behavior, which is one of the most important predictions of TPP. The lowest correlations are between Subjective Norms and Intention and Behavior data for both types of meat. Correlations between all variables in the model are statistically significant $(p<0.01)$. In addition to the Behavioral Intent and Behavior ways of the price $(\mathrm{P})$ variable which is added to

I: Socioeconomic and demographics characteristics on individuals who participated in the survey $(n=455)$

\begin{tabular}{|c|c|c|c|c|c|c|c|}
\hline & & $\mathbf{n}$ & $\%$ & & & $\mathbf{n}$ & $\%$ \\
\hline \multirow{2}{*}{ Gender } & Male & 244 & 53.6 & \multirow{4}{*}{ Monthly income $\left(£^{*}\right)$} & $0-1499$ & 79 & 17.4 \\
\hline & Female & 211 & 46.4 & & $1500-2499$ & 236 & 51.9 \\
\hline \multirow{6}{*}{ Age } & $18-24$ & 83 & 18.2 & & $2500-3499$ & 128 & 28.1 \\
\hline & $25-30$ & 90 & 19.8 & & $3500-<$ & 12 & 2.6 \\
\hline & $31-40$ & 140 & 30.8 & \multirow{4}{*}{ Education level } & Primary/sec. school & 186 & 40.9 \\
\hline & $41-50$ & 96 & 21.1 & & High school & 160 & 35.2 \\
\hline & $51-<$ & 46 & 10.1 & & University degree & 103 & 22.6 \\
\hline & \multicolumn{2}{|c|}{ Mean } & 35.2 & & Postgraduate & 6 & 1.3 \\
\hline \multirow{5}{*}{ Family size } & $1-2$ & 39 & 8.6 & \multirow{4}{*}{$\begin{array}{l}\text { Food expenditure } \\
\text { (£/month) }\end{array}$} & $0-249$ & 46 & 10.1 \\
\hline & $3-4$ & 201 & 44.2 & & $250-399$ & 121 & 26.6 \\
\hline & $5-6$ & 166 & 36.5 & & $400-599$ & 213 & 46.8 \\
\hline & $7-<$ & 49 & 10.8 & & $600-<$ & 75 & 16.5 \\
\hline & \multicolumn{2}{|c|}{ Mean } & 4.2 & \multirow{3}{*}{ Location of residence } & Provincial center & 195 & 42.9 \\
\hline \multirow{2}{*}{$\begin{array}{l}\text { Children in } \\
\text { the household }\end{array}$} & No & 141 & 31.0 & & County town & 188 & 41.3 \\
\hline & Yes & 314 & 69.0 & & Village & 72 & 15.8 \\
\hline
\end{tabular}

*(2017 Average exchange rate: 3.6515 €/1 \$) £: Turkish lira. 
our original TPB Model as an additional regressor in our work, new ways of modeling have been added in the process of modification. Especially in meat consumption area, researches used TPB put forward the feature of intentions as proximal determinants in consumption, that affected by attitudes, perceived behavioral control and, in a way, subjective norms in return (Povey et al., 2001). When coefficient estimates are examined, it can be said that Attitude and Perceived Behavior Control are more effective on both behavioral intention and behavior for the original model, but Subjective Norms are less effective. This result is in line with the findings of previous studies. Among the behavioral beliefs that determine the attitude of the consumers toward meat, the subjects such as health, satisfaction, nutritive value, meat safety and security, taste have come to the forefront. In particular, past experiences have been found to be important to control beliefs, which determine perceived behavioral control in meat consumption.

Meat prices were found to have a negative effect, as expected on Behavior and Behavioral Intent, and this effect was found to be higher in red meat consumption or purchase (Red meat consumption coefficient estimates are -0.188 for $\mathrm{BI}<-\mathrm{P}$ and $-0.212, \mathrm{p}>0.001$ for $\mathrm{B}<-\mathrm{P}$, white meat consumption coefficient estimates are -0.133 for $\mathrm{BI}<-\mathrm{P}$ and -0.058 , $\mathrm{p}>0.001$ for $\mathrm{B}<-\mathrm{P})$. The severity level of the effects of subjective norms and perceived behavioral control on red meat consumption behavior is slightly lower compared to white meat. In the consumption of red meat, it may be considered that some of the norms and various perceptions that individuals possess affect the behavior negatively. In general, other coefficient estimates were of similar importance.

In a study of the consumption of animal products in urban areas in Turkey, all products own-price elasticities are found to be negative and statistically significant and this shows that consumers are very sensitive to prices changes (Armagan and Akbay, 2008). As a matter of fact, in a study conducted in the city center and districts of Ankara, which is the capital of Turkey, the consumption amount of annual chicken meat was noted as $39.72 \mathrm{~kg}$ and price appropriateness was specified as the first factor in chicken meat consumption preference. In another study conducted in Turkey, among the most important factors affecting the purchase of chicken meat, its accessibility and price feasibility share the first two spot (Altuntaş and Doğan, 2017; Aral et al., 2013). The nutritional category that is most responsive to the expenditure variances is meat and meat products. The amount of the predicted expenditure fluctuations for the meat are generally higher than those of own price, which suggests that replacing price policies with income policies may be more effective in increasing meat consumption (Akbay et al., 2007).

More conflicted meat eaters were additionally found to hold less uplifting states of mind towards meat, and more likely to correlate meat with negative aspects, moral concerns, dangers for wellbeing and the environment, opposing to those who are less conflicted (Berndsen and van der Pligt, 2004). In addition to these issues contributing to the formation of negative attitudes, our study also added price increases in meat.

II: Correlations, coefficient estimates, importance level and total explained variance in meat consumption

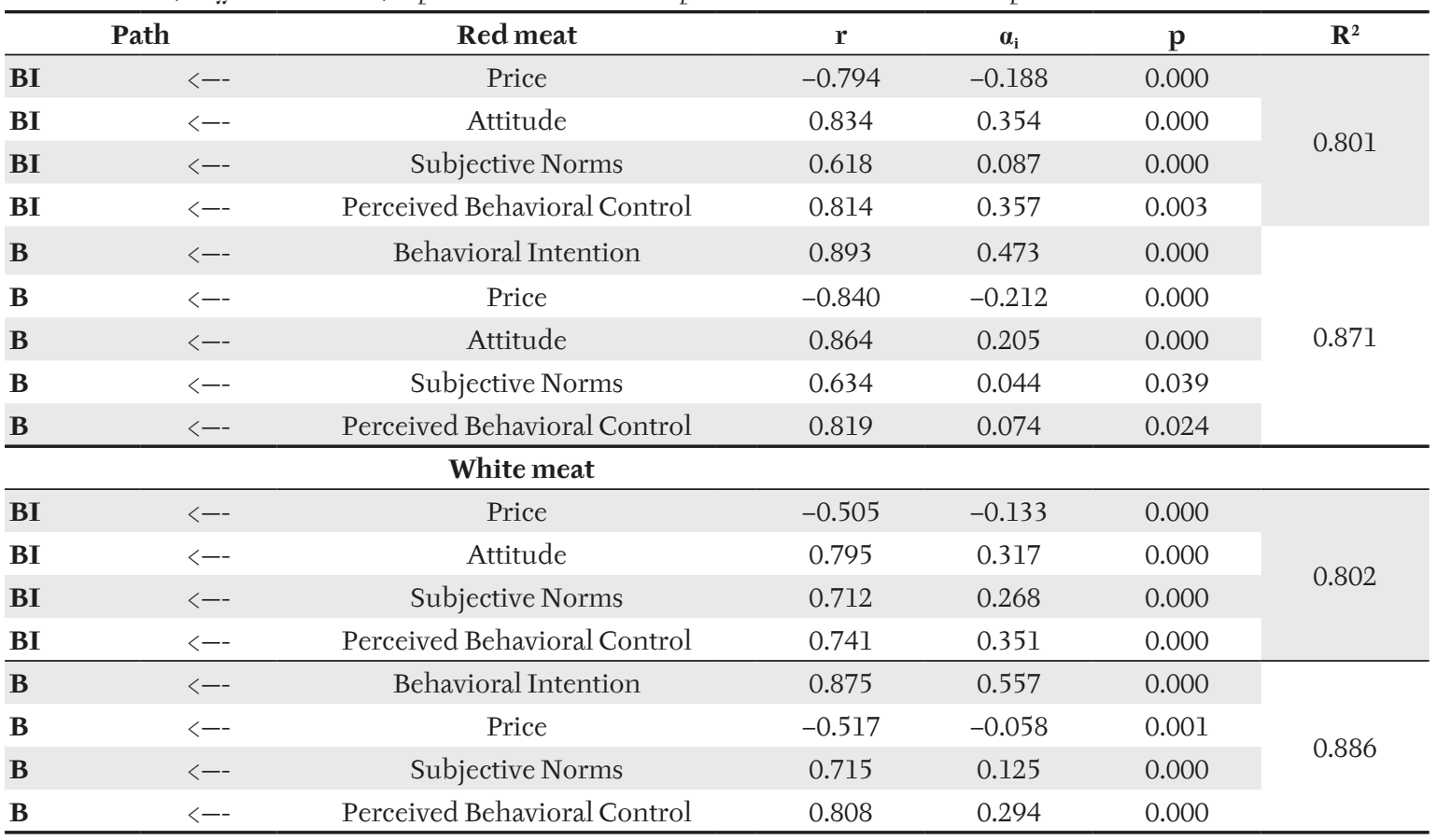

All correlation is significant at the 0.01 level (2-tailed). r: Spearman rank correlation. 


\section{Socioeconomic and demographic characteristics-consumption relation}

Demands for consumers' meat and meat products will vary, depending on household income level and other socioeconomic and demographic variables as well as the price of these products. The relationship between the amount of meat consumed by participants and socioeconomic and demographic variables is examined in Tab. III. According to the results of descriptive statistics, men consume more of both kinds of meat than women. According to the independent sample t-test, the meat consumption among the genders was found to be significantly different $(\mathrm{p}<0.001)$. Gender is seen as a strong marker for meat consumption in general and it is seen in this study that males have higher consumption levels than females. Similar findings are found in most of the meat consumption studies (Hayley et al., 2015; Rothgerber, 2013; Rubby and Heine, 2011; Kubberød et al., 2002a).
Differences between participant's ages and meat consumption amounts were found to be only important for consumers between the ages of $18-24$ and $31-40$ years $(p<0.05)$. However, it is known that with the advancing age in consumers, the amount of meat in the diet is decreasing due to the increasing health concerns (Verbeke and Vackier, 2005; Kubberød, et al., 2002b). It has been seen that consumers in our study started a trend in this direction starting from the age group of 41-50 and decreased their consumption of fresh meat. It has been found that there is an inverse relationship between the amount of fresh meat consumed by participating families and family size. That is, as the population of the family increases, the amount of fresh meat consumed in that family decreases. The difference between the consumption of red meat by the family consist of 1-2 persons and the consumption of the more crowded families was found statistically significant $(p<0.05)$. As the size of the households in this region increases, the food

III: Changes in fresh meat consumption by socioeconomic variables $(n=455)$

\begin{tabular}{|c|c|c|c|c|}
\hline Items & Variables & $\mathbf{n}$ & $\begin{array}{c}\text { Red meat } \\
\text { (person/g/day) }\end{array}$ & $\begin{array}{c}\text { White meat } \\
\text { (person/g/day }\end{array}$ \\
\hline \multirow{2}{*}{ Gender } & Male & 244 & 55.83 & 104.76 \\
\hline & Female & 211 & 36.69 & 86.87 \\
\hline \multirow{5}{*}{ Age } & $18-24$ & 83 & 42.32 & 91.22 \\
\hline & $25-30$ & 90 & 48.15 & 97.33 \\
\hline & $31-40$ & 140 & 50.11 & 101.56 \\
\hline & $41-50$ & 96 & 46.81 & 95.12 \\
\hline & $51-<$ & 46 & 43.69 & 91.51 \\
\hline \multirow{4}{*}{ Family size } & $1-2$ & 39 & 58.93 & 102.43 \\
\hline & $3-4$ & 201 & 48.19 & 97.31 \\
\hline & $5-6$ & 166 & 43.88 & 95.01 \\
\hline & $7-<$ & 49 & 42.76 & 93.16 \\
\hline \multirow{2}{*}{ Children in the household } & No & 141 & 44.16 & 93.68 \\
\hline & Yes & 314 & 48.21 & 97.71 \\
\hline \multirow{4}{*}{ Monthly income (E) } & $0-1499$ & 79 & 39.06 & 88.83 \\
\hline & $1500-2499$ & 236 & 46.69 & 98.02 \\
\hline & $2500-3499$ & 128 & 51.07 & 96.75 \\
\hline & $3500-<$ & 12 & 60.32 & 113.04 \\
\hline \multirow{4}{*}{ Education level } & Less than high school & 186 & 42.96 & 92.61 \\
\hline & High school & 160 & 48.57 & 98.83 \\
\hline & University degree & 103 & 50.18 & 98.58 \\
\hline & Postgraduate & 6 & 72.22 & 116.40 \\
\hline \multirow{4}{*}{ Food expenditure (t/month) } & $0-249$ & 46 & 39.26 & 87.25 \\
\hline & $250-399$ & 121 & 48.76 & 95.58 \\
\hline & $400-599$ & 213 & 46.88 & 97.55 \\
\hline & $600-<$ & 75 & 48.96 & 100.46 \\
\hline \multirow{3}{*}{ Location of residence } & Provincial center & 195 & 50.03 & 98.75 \\
\hline & County town & 188 & 45.18 & 95.80 \\
\hline & Village & 72 & 43.27 & 91.99 \\
\hline Average & & 455 & 46.95 & 96.46 \\
\hline
\end{tabular}


expenditures also decrease proportionally, so the amount of food per capita in the more crowded families may be considered reduced. Having children have caused families to consume more red or white meat, but the difference between these consumption quantities is not significant. Given the large shifts towards the meat-weighted nutrition trend in the world, it can be said that factors such as economic development, food industry development and urbanization play a key role and interact with each other in these shifts (Graça, 2016). With respect to economic improvement, income increase among the population is viewed as a key indicator of expanded meat consumption at the national means (Delgado et al., 1999). Even if the share of food expenditures of the individuals with increasing total income decreases, the quantity increases in absolute terms. The higher consumption of animal products such as meat and milk is the most significant effect of these increases (Sans and Combris, 2015). The differences of fresh meat consumption between families in the lowest income group (0-1499 €/monthly income) and other income groups (except for 2nd and 3rd income groups in consumption of white meat) were statistically significant $(p<0.05)$. In general, the income increases with the increase of the education levels of the persons. When considered in this context, the meat consumption of consumers who are interviewed within the scope of the research increases with the increase of education level. In terms of both meat types, participants' fresh meat consumption increased as their education level increased. The difference in red meat consumption among consumers in the primary education/secondary education group and those in the other education group is statistically significant $(p<0.05)$. For white meat consumption, the differences between the consumption of different education levels do not matter. Consumers' individual and family food expenditures vary depending on many variables such as income, population, dietary habits, maternal employment status and food prices (O'Neill, et al., 2014; Lorcu and Bolat, 2012; Albisu et al., 2011; Carrillo, et al., 2011; Sobal and
Bisogni, 2009; Drewnowski and Darmon, 2005; Gossard and York, 2003; Saba and Di Natale, 1999; Shepherd, 1999; Worsley and Skrzypiec, 1998; Lennernäs, et al., 1997). When the changes in meat consumption and increase or decrease of food expenditures of consumers are examined, it can be seen that, as expected, there is a direct proportion. In the consumption of red meat, the difference between meat consumption of consumers in the first group and the second and fourth groups are statistically significant, and the difference between the consumption of white meat in the first group and the third and fourth groups are statistically significant $(\mathrm{p}<0.05)$. Such changes are nonstop: for example, socioeconomic and demographic variables such as place of home (urban or rural) and social class have been seen to be related with meat dietary patterns (Gossard and York, 2003). When it is examined whether the residential areas of the participating consumers cause a difference in meat consumption, it is seen that consumption of white meat decreased from urban areas towards rural areas, but this decline was not significant. Similarly, consumers' consumption of red meat decreased from city centers to rural areas; however, the difference between provincial centers and district and village settlements was significant $(p<0.05)$. It is demonstrated by the food consumption results that food consumption motives of Turkish families cannot be totally associated with price and income changes. Our discoveries recommend that socioeconomic and demographic reasons are as equally important as conventional financial variables in clarifying seen differences in food consumption motives. Especially, family size and composition, education and age of the head of the family, and some other occasional and provincial contrasts are considered to be vital determinants of the use allotment among food products (Akbay, et al., 2007). Socioeconomic and demographic variables such as gender, age (in some way), family size, income level, level of education, total food expenditure and place of a home have caused significant differences in fresh meat consumption, as demonstrated in similar studies.

\section{CONCLUSIONS}

While developed economies have nutritional problems due to excessive meat consumption, underdeveloped countries have health problems due to the lack of these foods. As a result, practices and interventions encouraging slimming towards vegetative diets in nutrition in developed countries are at the forefront. Opposing to this, in undeveloped countries efforts to close the animal protein deficits are at the forefront.

Attitudes formed in consumers toward red meat, perceived behavioral control and price have been determined as the most influential factors affecting behavior and behavioral intention. For white meat, the effect of the price variable is much lower. Therefore, only consumers' incomes and product prices will not be enough to determine the consumer's meat consumption and preferences. Behavioral beliefs that determine the attitude of the consumers towards the meat, their judgment of the nature of these beliefs and past experiences from the control beliefs that constitute perceived behavioral control have been identified as important variables. The TPB model produces good results in predicting food consumption behaviors and can be used to determine the relative importance of different factors. There are also macro and micro factors affecting an individual's meat consumption. 
Some of these factors have a positive effect on consumers' consumption of meat, while others have a negative effect. The results of this research provide information and conclusions that can be used by policy makers and administrators. Decision-makers can apply encouragement or abandonment policies according to the effects these factors have and taking into account social needs.

In our study, it was determined that various characteristics of the individuals, who were examined in meat consumption research, were significantly related. Individual meat consumption behaviors are shaped by the interactions between socioeconomic and demographic factors and macroeconomic and physiological factors. Among the issues considered primarily in the US and European Union countries in meat consumption, there are expectations and concerns such as traceability, production methods, environmental impacts, food quality and safety, meat welfare and animal welfare practices. Among the reasons for negative attitudes such as animal rights and environmental sensitivities as well as health concerns related to consumption of red meat by consumers, it would be appropriate for Turkey to include red meat prices. In this context, increases in white meat consumption can be attributed to the substitution relationship, which is due to the high price increases in red meat. In Turkey, we can see the substitution-related increases in white meat demand as a positive development, which means a healthier diet.

Production targets and policies should be shaped taking into consideration all the factors that have an impact on the consumption of fresh meat. Closure of the supply deficit of animal products in the rapidly growing young population in Turkey and achieving adequate consumption levels should be the main targets. In general, the change in the price of food products or the effect of other macro and micro factors on consumption manifests itself as a quantity or product variety change. Therefore, in the subsequent consumption studies, the changes in the amount of consumption and product types should be considered together.

\section{REFERENCES}

AJZEN, I. 1991. The theory of planned behavior. Organizational Behavior and Human Decision Processes, 50(2): 179-211.

AJZEN, I. 2005. Attitudes, Personality and Behavior. $2^{\text {nd }}$ Edition. Milton-Keynes, England: McGraw-Hill, Open University Press.

AJZEN, I. and FISHBEIN, M. 2005. The influence of attitudes on behavior. In: D. ALBARRACÍN, D., JOHNSON, B. T. and ZANNA, M. P. (Eds.). The Handbook of Attitudes. Mahwah, N. J.: Lawrence Erlbaum Associates, pp.173-221.

AJZEN,I.2006. Constructing a TpB Questionnaire: Conceptualand methodologicalconsiderations. Universität Bielefeld. [Online]. Available at: http://www.uni-bielefeld.de/ikg/zick/ajzenconstructionatpbquestionnaire.pdf [Accessed: 2017, March 15].

AJZEN, I. 2011. The theory of planned behaviour: reactions and reflections. Psychology $\sigma$ Health, 26(9): 1113-1127.

AKBAY, C., BOZ, I. and CHERN, W. S. 2007. Household food consumption in Turkey. European Review of Agricultural Economics, 34(2): 2009-231.

ALBISU, L. M., GRACIA, A. and SANJUÁN, I. 2011. Demographics and Food Consumption: Empirical Evidence. In: LUSK, J. L., ROOSEN, J. and SHOGREN, J. F. (Eds.). The Oxford Handbook of the Economics of Food Consumption and Policy. Oxford University Press.

ALTUNTAŞ, B. and DOĞAN, H. G. 2017. Determination the poultry meat consumption habits and the factors affecting purchasing decision of households in Kırşehir Province (Turkey). Journal of Agricultural Faculty of Gaziosmanpasa University, 34(2): 20-28.

ARAL, Y., AYDIN, E., DEMIR, P., AKIN, A. C., CEVGER, Y., KAYA KUYULU, Ç. Y. and ARIKAN, M. S. 2013. Consumer preferences and consumption situation of chicken meat in Ankara Province, Turkey. Turkish Journal of Veterinary and Animal Science, 37: 582-587.

ARMAGAN, G. and AKBAY, C. 2008. An econometric analysis of urban households' animal products consumption in Turkey. Applied Economics, 40(15): 2029-2036.

BARREIRA, M. M. and DUARTE, M. F. 1997. An analysis of changes in Portuguese meat consumption. In: WIERENGA, B., VAN TILBURG, A., GRUNERT, K., STEENKAMP, J. B. E.M. and WEDEL, M. (Eds.). Agricultural Marketing and Consumer Behavior in a Changing World. Springer Science + Business Media, pp. 261-273.

BERNDSEN, M., and VAN DER PLIGT, J. 2004. Ambivalence towards meat. Appetite, 42(1): 71-78.

BLAYLOCK, J., SMALLWOOD, D., KASSEL, K., VARIYAM, J. and ALDRICH, L. 1999. Economics, food choices, and nutrition. Food Policy, 24(2-3): 269-286.

BYRNE, B. M. 2010. Structural equation modelling with Amos: Basic concepts, applications and programming. $2^{\text {nd }}$ Edition. Taylor and Francis Group. 
CARRILLO, E., VARELA, P., SALVADOR, A. and FISZMAN, S. 2011. Main factors underlying consumers' food choice: A first step for the understanding of attitudes toward "healthy eating". Journal of Sensory Studies, 26(2): 85-95.

COSGROVE, M., FLYNN, A. and KIELY, M. 2005. Consumption of red meat, white meat and processed meat in Irish adults in relation to dietary quality. British Journal of Nutrition, 93: 933-942.

DELGADO, C., ROSEGRANT, M., STEINFELD, H., EHUI, S. and COURBOIS, C. 1999. Livestock to 2020: The next food revolution. IFPRI Food, Agriculture, and the Environment Discussion Paper 28. Washington, DC. USA: IFPRI. [Online]. Available at: http://hdl.handle.net/10568/333 [Accessed: 2017, April 02].

DANIEL, C. R., CROSS, A.J., KOEBNICK, C. and SINHA, R. 2011. Trends in meat consumption in the United States. Public Health Nutrition, 14(4): 575-583.

DREWNOWSKI, A. and DARMON, N. 2005. Food choices and diet costs: an economic analysis. The Journal of Nutrition, 135(4): 900-904.

FAGERLI, R. A. and WANDEL, W. 1999. Gender differences in opinions and practices with regard to a "Healthy Diet". Appetite, 32(2): 171-190.

GOLDBERG, J. P. and HELLWIG, J. P. 1997. Nutrition research in the media: the challenge facing scientists. Journal of the American College of Nutrition, 16: 544-550.

GOSSARD, M. H. and YORK, R. 2003. Social structural influences on meat consumption. Human Ecology Review, (10)1: 1-9.

GRAÇA, J. 2016. Towards an integrated approach to food behaviour: meat consumption and substitution, From Context to Consumers. Psychology, Community $\odot$ Health, 5(2): 152-169.

GUL, U. and UZUN, B. 2015. Red meat Status and Forecast 2015. Ankara, Turkey: Agricultural Economic and Policy Development Institute, Publication Number 255. [Online]. Available at: http://www.tepge.gov.tr/ Dosyalar/Yayinlar/6279a7177c904783906c672ff88d7658.pdf [Accessed: 2017, March 18].

HAYLEY, A., ZINKIEWICZ, L. and HARDIMAN, K. 2015. Values, attitudes, and frequency of meat consumption. Predicting meat-reduced diet in Australians. Appetite, 84: 98-106.

HIGUCHI, A., DÁVALOS, J. and HERNANI-MERINO, M. 2017. Theory of planned behavior applied to fish consumption in modern Metropolitan Lima. Food Science and Technology, 37(2): 202-208.

JIMIN, W., YUE, Z. Z. and COX, R. J. 2005. Animal product consumption in China. Australasian Agribusiness Review, 13: Paper 2.

KARLI, B., ERTATIS, F., YUKSEL, F., TEKIN, A. and GUL, M. 2017. Determination of red meat consumption habits. The case of Isparta Province. Scientific Papers Series Management, Economic Engineering in Agriculture and Rural Development, 17(2): 197-205.

KUBBERØD, E., UELAND, Ø., TRONSTAD, A. and RISVIK, E. 2002a. Attitudes towards meat and meateating among adolescents in Norway: A qualitative study. Appetite, 38: 53-62.

KUBBERØD, E., UELAND, Ø., RØDBOTTEN, M., WESTAD, F., and RISVIK, E. 2002b. Gender specific preferences and attitudes towards meat. Food Quality and Preferences, 13(5): 285-294.

LEA, E. and WORSLEY, A. 2001. Influences on meat consumption in Australia. Appetite, 36: 127-136.

LENNERNÄS, M., FJELLSTRÖM, C., BECKER, W., GIACHETTI, I., SCHMITT, A., WINTER, A. M., and KEARNEY, M. 1997. Influences on food choice perceived to be important by nationally representative samples of adults in the European Union. European Journal of Clinical Nutrition, 51(Suppl. 2): 51.

LORCU, F. and BOLAT, B. A. 2012. The analysis of the preferences of the consumption of red meat in the province of Edirne. Journal of Tekirdag Agricultural Faculty, 9(1): 71-85.

MITTERER-DALTOÉ, M. L., CARRILLO, E., QUEIROZ, M. I., FISZMAN, S., and VARELA, P. 2013. Structural equation modelling and word association as tools for a better understanding of low fish consumption. Food Resources International, 52(1): 56-63.

MOD. 2014. The Tenth Development Plan (2014-2018). Special Commission Report (Animal Husbandry). Ministry of Development, Republic of Turkey, Publication Number: KB: 2873 - ÖİK: 723. [Online]. Available at: http://www.mod.gov.tr/Pages/DevelopmentPlans.aspx [Accessed: 2017, April 06].

OECD/FAO. 2016. OECD-FAO Agricultural Outlook 2016-2025. Paris, France: OECD Publishing. [Online]. Available at: http://www.fao.org/3/a-i5778e.pdf [Accessed: 2017, March 18].

OECD/FAO. 2014. Agricultural Outlook 2013-2022, Highlights. [Online]. Available at: http://www.agri-outlook. org/highlights-2013-en.pdf [Accessed: 2017, March 12].

O'NEILL, V., HESS, S. and CAMPBELL, D. 2014. A question of taste: recognizing the role of latent preferences and attitudes in analysing food choices. Food Quality and Preference, 3: 299-310.

POVEY, R., WELLENS, B. and CONNER, M. 2001. Attitudes towards following meat, vegetarian and vegan diets: An examination of the role of ambivalence. Appetite, 37(1): 15-26.

ROTHGERBER, H. 2013. Real men don't eat (vegetable) quiche: Masculinity and the justification of meat consumption. Psychology of Men $\sigma$ Masculinity, 14(4): 363-375.

RUBY, M. B. and HEINE, S. J. 2011. Meat, morals, and masculinity. Appetite, 56(2): 447-450.

SABA, A. and DI NATALE, R. 1999. A study on the mediating role of intention in the impact of habit and attitude on meat consumption. Food Quality and Preference, 10: 69-77. 
SACLI, Y. and OZER, O. O. 2017. Analysis of factors affecting red meat and chicken meat consumption in Turkey using an ideal demand system model. Pakistan Journal of Agricultural Sciences, 54(4): 933-942.

SANS, P., and COMBRIS, P. 2015. World meat consumption patterns: An overview of the last fifty years (1961-2011). Meat Science, 109: 106-111.

SHEPHERD, R. 1999. Social determinants of food choice. Proceedings of the Nutrition Society, 58(4): 807-812.

SOBAL, J. and BISOGNI, C. A. 2009. Constructing food choice decisions. Annals of Behavioral Medicine, 38(Suppl. 1): 37-46.

TUDORAN, A., OLSEN, S. O. and DOPICO, D. C. 2009. The effect of health benefit information on consumers' health value, attitudes and intentions. Appetite, 52(3): 568-579.

TUIK. 2017a. Consumer Price Index Database. Turkish Statistical Institute. [Online]. Available at: http://www. tuik.gov.tr/PreIstatistikTablo.do?istab_id=653 [Accessed: 2017, March 20].

TUIK. 2017b. Livestock Statistics Database. Turkish Statistical Institute. [Online]. Available at: http://www.tuik. gov.tr/PreIstatistikTablo.do?istab_id=685 [Accessed: 2017, March 21].

UZMAY, A. and CINAR, G. 2017. Factors affecting the domestic and imported cattle meat consumption probability of consumers in Turkey. Journal of Agricultural Science and Technology, 19: 501-510.

YILDIRIM, I. and CEYLAN, M. 2007. A comparative assessment of urban and rural households' behaviors towards fresh red meat consumption: A case study in Eastern Part of Turkey. Nutrition $\sigma$ Food Science, 37(4): 222-233.

VERBEKE, W. and VACKIER, I. 2005. Individual determinant of fish consumption: application of the theory of planned behaviour. Appetite, 44, 67-82.

VERMIER, I. and VERBEKE, W. 2008. Sustainable food consumption among young adults in Belgium: Theory of planned behaviour and the role of confidence and values. Ecological Economics, 64: 542-553.

VERSTUYF, J., PATRICK, H., VANSTEENKISTE, M. and TEIXEIRA, P. J. 2012. Motivational dynamics of eating regulation: A self-determination theory perspective. International Journal of Behavioral Nutrition and Physical Activity, 9(1): Article 21.

WORSLEY, A. and SKRZYPIEC, G. 1998. Do attitudes predict red meat consumption among young people? Ecology of Food and Nutrition, 37: 163-195.

Bekir Demirtas: bdemirtas@mku.edu.tr 